south-west. Thus the Cretaceous coals at Crazy Mountain, Montana, are too thin to be mined, except for local use; but at Lewiston, Montana, the Lower Cretaceous coal from the Kootenai formation is of great value, though high in sulphur; the Grand Mesa field in Colorado has an estimated supply of $\mathrm{I}_{5}, 000,000,000$ tons of Mesaverde coal, of a calorific value of from 8600 to 13,600 thermal units.

A second Bulletin (No. 380), "Contributions to Economic Geology, 1908," deals with minerals except fuels. Mr. C. W. Hayes has superintended the preparation of the reports on the non-metals and iron ores, and $\mathrm{Mr}$. W. Lindgren those on the rest. The Bulletin consists of twenty-five papers and numerous bibliographies. Some of the reports are based upon only a few hours' or a day's visit, but others are preliminary reports based upon a donger study. J. S. Diller and G. F. Kay describe the Grants Pass goldfield in Oregon, which is one of those frequent and disappointing fields where the gold is very widely distributed through innumerable small veins and veinlets; the absence of well-defined lodes is unfavourable to profitable mining, until some clue be discovered to the distribution of the richer patches. The ores are found in association with greenstones and granodiorites intruded into altered sediments. The placer deposits are widely scattered, and are worked by many small mines, employing from three to five men each. Some of the placers are Cretaceous shore deposits.

Mr. F. L. Hess reports upon the tin, wolfram, and tantalum deposits of South Dakuta. Tin is so scarce in the United States that much interest was excited by its discovery in pegmatite dykes traversing the Algonkian schists at Harney Peak. Assays showed the presence of up to 6 per cent. of tin, and the Harney Peak Tin Company was established to work the deposits on a big scale. Three million dollars of English money, in addition to some American, was spent in the venture, and Mr. Hess tells us that the 5000 tons of ore put through the mill yielded only 0.25 per cent. of tin. The tin cost more than its weight of gold. This failure is, perhaps, not surprising, as pegmatite dykes have never been found to pay as tin ores except on a small scale. The wolfram ores of the same locality are known from the descriptions of $\mathrm{Mr}$. J. D. Irving, and though Mr. Hess does not altogether agree with his theoretical conclusions, he rentarks that Mr. Irving's prediction as to the limited economic value of the deposits has been fully justified. This wolfram ore is of some interest, as it occurs as a replacement of dolomite and was introduced by solutions rising along vertical fractures.

Of the four papers in this Bulletin dealing with iron ores, one of the most interesting is by Mr. E. C. Harder, on the ores of the Appalachian region in Virginia. Some of the ores occur in the pre-Cambrian schists and crystalline rocks of the country at the eastern foot of the Alleghany Mountains; but the ores are not commercially important. They, however, include the interesting titaniferous magnetites of the Blue Ridge, which have been formed as segregations in a basic syenite (unakite); and the truly magmatic origin of these small bunches of ore is shown by the many included specks of minerals belonging to the enclosing rocks. The more important ores occur in the Palæozoic rocks of the Appalachian plateau, including "brown ores" of three distinct origins. They are "mountain ores" associated with Lower Vambrian quartzites, "valley ores" found in residuas material formed from Cambrian limestone, and the Oriskany ores, which occur as replacements in the Silurian Lewistown limestone.

The manganese ores of the United States have been studied by Mr. Harder, who promises a special bulletin upon them. The ores are widely distributed, but are not much mined, since they usually occur in pockets of not exceeding 25,000 tons, and cannot compete with the imports.

Among reports on the non-metallic minerals is a short note on the mica deposits of southern Dakota, by $\mathrm{Mr}$. D. B. Sterrett. The mica is found in pegmatites, which are sometimes intrusive dykes and sometimes veins due to pneumatolytic action. The two types pass imperceptibly into one another. The supply of sheet mica for lamps and furnace doors exceeds the demand, and most of the mica obtained is employed for the manufacture of electric NO. 2 I 38 , VOL. 84$]$ machinery. There is a short report by E. G. Woodrow on the sulphur deposits near Thermopolis, Wyoming; the sulphur is deposited by hot springs, where the water comes in contact with limestone. The sulphur is deposited as crystals, and also as masses replacing the limestone.

Mr. Matson contributes some notes on the clays of Florida, and describes the ball clays, which are usually described as kaolin, as they are white burning, and can be used for either porcelain or white earthenware. As they are sedimentary, Mr. Matson seems unnecessarily doubtfü? as to whether they can be included. in kaolin.

Bulletin No. 374 describes the mineral resources of the Kotsina-Chitina region of Alaska, by F. H. Moffit and A. G. Maddren. The name Chitina means " copper river," and copper is the most promising mineral of the district, though it has not yet been proved to occur in conditions under which it can be profitably mined. The district also contains some coal and alluvial gold, which has been worked since 1902. The copper is mostly found in the lower part of the Triassic Chitistone limestone, where it rests on the Nikolai greenstone, a series of basaltic lava flows, from which the copper is thought to have been derived.

The investigations on the general mineral resources of Alaska made in 1908 are reported in Bulletin 379 , in a series of nineteen papers, edited by Mr. A. H. Brooks. The mining industry as a whole suffered a decline in output during that year owing to the diminished yield of copper. Gold is still the main source of wealth, though the yield fell slightly below that of 1906 . Four-fifths of the supply is alluvial, and the cost of working the placers is so heavy that only the richest art worked. The lode mines, on the other hand, are low grade, the most important being those of the Alaska Treadwell group. Its ore yiclds only $2 \cdot 3$ dollars of gold per ton, but, owing to the large quantity and easy methods of mining, it can be worked at a cost of one dollar a ton. In spite of local predictions, dredges have already proved successful, and their use must add greatly to the available mineral wealth of the district. The most interesting placer deposits are those at Nome, on the Seward Peninsula, where the famous Third Beach, discovered in 1905, is still being worked. Alaskan shore placers are at present the most important that are being worked anywhere for gold. The report by Moffit and Knopf on the Nabesma-White River district shows that the copper there occurs in Carboniferous basaltic amygdaloids and in limestone along the contact with some intrusive diorites; but the fabulously rich copper deposits reported have not yet been found.

J. W. G.

\section{AIRSHIP FLIGHTS.}

IFOR some time public attention has been directed chiefly upon the records achieved by aëroplanes. Two airship flights undertaken during the past few day serve to illustrate what may be accomplished by dirigibl balloons. On October 15, at about 8 a.m., Mr. Walter Wellman left Atlantic City in his gigantic airship America with the object of voyaging to Europe; and on the following day the frameless airship Clement-Bayard No. 2 travelled from Lamotte-Breuil by Compiègne, to Wormwood Scrubbs-a distance of nearly 260 miles-in six hours.

The Clément-Bayard No. 2 is $25^{\mathrm{I}}$ feet long, and its greatest diameter 44 feet 4 inches. The Times gives the following particulars of the construction of this airship.

Inside the bas there are two compensating air balloons which can be filled separately. The car, 26 feet 3 inches beneath the envelope, is 147 feet 5 inches long. The stern is provided with a keel to preserve stability. The metallic framework is composed of triangular steel rafters, except in the portion occupied by the motors, crew, and passengers, where they are quadrangular. At the hind extremity this framework takes a turn upwards to support the equilibrator, a large triplane-like apparatus with eight square compartments resembling the main cell of a Voisin aëroplane, controlling ascent and descent. The equilibrator, comprising the rudder, composed of two mobile planes on vertical axes at either end of the triplane, is worked by an irreversible mechanism. There are two propellers driven by two I20 horse-power Clément-Bayard 
motors mounted on a steel frame furnished with springs to deaden the vibration. Each propeller is driven by its own motor, but, in case of need, one single motor can drive the two propellers at the same time. The gear for the reduction of speed is placed in the prolongation of the driving shaft, beyond the propeller. The two propellers, of polished wood, have a diameter of 19 feet 8 inches, and are placed laterally in front, one on each side of the car, projecting beyond the sides of the steel framework. They occupy a position midway between the car and the balloon. The tractive power of each propeller is ascertainable at any moment. The dirigible is built to be able to ascend to an altitude of 6560 feet, and it is capable of travelling about 750 miles without replenishing its supplies of gas and fuel.

The Clement-Bayard No. 2 left Lamotte-Breuil with a crew of seven people, including $\mathrm{M}$. Clément, the designer of the vessel, on October I6 at 7.5 a.m. (G.M.T.), passed over Amiens at 8.29 and Boulogne at I0.15. The Channel was crossed in some fifty-five minutes, and Ashford seen at 11.45 a.m. Tonbridge was passed at 12.29 p.m., the Tower Bridge at I.4, and Wormwood Scrubbs was reached at $\mathbf{1 . 2 5}$. The whole distance, of nearly 260 miles, was thus covered in a little more than six hours at an average speed of about 43 miles an hour. The greatest altitude attained during the flight was between 800 feet and 900 feet, but most of the travelling was done between 600 feet and 700 feet. 'The average temperature was $60^{\circ} \mathrm{F}$. The success of the enterprise must be attributed largely to the very favourable weather conditions which prevailed during the flight. There was only a slight wind, and it was in a direction which assisted the movement of the airship, so that the demand made upon the power of independent navigability was not great. We still await the construction of an airship which will satisfy the War Office tests, one of which is that the vessel has to traverse a triangular course of 300 miles within a fixed time-limit. When this has been done it will be possible to form a satisfactory estimate of the advantages of power-driven airships over the ordinary spherical balloon.

The America, in which $\mathrm{Mr}$. Wellman with five companions made the daring attempt to cross the Atlantic, is a dirigible of the frameless type; it is 228 feet long, its greatest diameter $5^{2}$ feet, and it has a volume of 345,000 cubic feet. According to the Daily Telegraph (under the auspices of which, with the New York Times and other American papers the flight was undertaken), the balloon is composed of three thicknesses of cotton and silk gummed together with rubber to make it gastight, and weighs $4850 \mathrm{lb}$. Underneath the balloon is suspended by steel cables the car, weighing $4400 \mathrm{lb}$. This car is built of the highest grade steel tubing, and in places withstands stresses of twelve tons. It is 156 feet in length, and the steel tank at its base is 75 feet long, with a capacity of 1250 gallons of gasoline. The engines, three in number (two of 80 horse-power and a service motor of ten horse-power), are placed in the steel car. Each of the large motors drives a pair of twin screws, and each propulsion system is independent of the other. The motors and other machinery weigh about $1_{500} \mathrm{Ib}$. An electric light system, a wireless telegraph equipment, and a telephone connecting the different parts of the ship were installed.

Hanging from the airship by a steel cable is the equilibrator, a part of which floated upon the sea, the other being suspended vertically in the air. The purpose of this is to act as an automatic regulator of the upward and downward movements of the airship. When the ship rises it must lift some of the equilibrator from the sea in order to go up, and this added weight checks the rising movement. Conversely, when change of temperature or accumulation of moisture caused the airship to descend, a greater part of the equilibrator was?let down upon the sea, thus reducing the weight carried by the balloon and checking the descent.

The total supply of gasoline carried was in,00o lb., or about I80o gallons, which was considered sufficient to drive the airship from Atlantic City to Europe. The distance is about 3000 miles. With one engine running the airship could make a speed of 20 miles per hour, and the quantity of gasoline carried would run one engine 200 NO. 2 I 38 , VOL. 84$]$ hours. With both engines running the ship's speed in still air could be about 26 miles per hour.

After leaving Atlantic City at 8.5 a.m. on Saturday morning, October 15 , the America travelled 20 miles in the first hour, but later the rate was reduced to 15 miles an hour. Nantucket Island, which is about 300 miles from the starting place, was reached in twenty-four hours. A wireless message was received from $\mathrm{Mr}$. Wellman at x 2.45 p.m. on Sunday, October 16, when the airship passed out of range of communication with Nantucket Island. The vessel was then directed to the north-east, and early on the morning of October 17 was believed to be travelling between Nantucket Island and Nova Scotia. At 4.30 on October I 8 the airship was sighted in distress by the Royal Mail Steam Packet Company's steamer Trent, and after some difficulty Mr. Wellman and his crew were rescued and taken on board, the airship being abandoned. The position in which this occurred was latitude $35^{\circ} 43^{\prime} \mathrm{N}$. and longitude $68^{\circ} 18^{\prime} \mathrm{W}$., which is nearly 400 miles east of Cape Hatteras, on the North Carolina coast. The total distance covered by the airship appears to have been about 900 miles, and the duration of the voyage, during which she was in the air continuously, was sixty-nine hours.

\section{MATHEMATICS AND PHYSICS AT THE BRITISH ASSOCIATION}

THE address of the president of Section A, Prof. E. W. Hobson, was read on Thursday, September. I ; this has appeared in full in these columns (NATURE, September I, p. 284). It was succeeded by a paper-probably the most important paper read at the meeting-by Sir J. J. Thomson on positive rays. By the use of very large vacuum tubes Sir Joseph has been able to investigate the discharge at higher vacua than hitherto. Specially studying the rays which pass through a hole in the kathode, he detects :-(r) Rays undeviated by magnetic or electric forces. (2) Secondary positive rays, produced by these, which are deflectable by both forces, have a constant velocity of about $2 \times 10^{8} \mathrm{~cm} . / \mathrm{sec}$, at all pressures and potential differences. The value of $\mathrm{e} / \mathrm{m}$ for these is $\mathrm{IO}^{4}$. They are accompanied by negatively charged ones similar in every respect to the positive ones, except in respect to charge. (3) Rays characteristic of the gases in the tube, conspicuous only when the pressure is low. Their velocity varies with the potential difference. When several gases. are present, the maximum kinetic energy of the rays from each gas appears to be the same and equal to that due to a fall through the potential difference between the negative glow and the kathode. The value of $e / m$ is inversely proportional to the atomic weight of the gas. They are probably atoms carrying unit positive charge; in the case of hydrogen there are rays corresponding to the molecule as well. Some of these have negatively charged rays associated with them. In a magnetic field the rays from a mixture of gases spread out into a sort of spectrum. With carbon monoxide two bands are formed, one due to carbon, the other to oxygen. As exceedingly small quantities of gas may be dealt with in this way, it appears probable that interesting results may follow from the application of this method to the analysis of gases in vacuum tubes. (4) Retrograde rays, travelling: from the kathode in the same direction as the kathode rays. These are of types (I) and (2). They have negativeconstituents.

Dr. R. A. Houston followed with an exhibition of a spectrophotometer of the Hüfner type, which he has: previously described in the Phil. Mag. for February, 1908, and with a description of a new and simple means of producing interference bands. An approximately rightangled prism is placed in front of a slit; the two emergent beams produce interference bands in front of the prism. This is being used as a student's exercise; it does not appear, however, that the bands can be put to any practical use. A new gyroscopic apparatus was next exhibited by Prof. A. E. H. Love. The machine consists essentially of a pair of bicycle wheels fixed to a round steel bar as an axle. The bar is prolonged beyond one wheel to carry a wooden wheel, by means of which it can be set 